\title{
THE ANALYSIS OF QUALITY AND FOOD SAFETY ON FROZEN TIGER SHRIMP (PENAEUS MONODON) HANDLING IN CENTRAL JAVA, INDONESIA
}

\author{
Erawati Neni ${ }^{*}$, Darmanto Ys, Winarni A. Tri \\ Post-graduate Studies of Coastal Resources Management, Faculty of Fishery and Marine, \\ Diponegoro University of Semarang, Central Java, Indonesia \\ ${ }^{\star}$ E-mail: erawatineni@gmail.com
}

\begin{abstract}
Shrimp is one of Indonesia's fishery commodities that are still excellent. The value of shrimp exports was at the first rank for fishery products besides tuna. In January to August 2016, Indonesia's shrimp exports reached 136.3 thousand tons with a value of US $\$ 1.13$ billion (BPS). The purpose of this research is to analyze the quality and food safety of frozen tiger shrimp that have been handled and processed by fish processing units in Central Java, Indonesia. This research uses descriptive and purposive random sampling method, by taking sample of raw material and final product of frozen tiger shrimp at three processing units in Central Java of Indonesia periodically. The results of organoleptic, microbiological and chemical tests show that the processing units in Central Java has performed good quality of frozen tiger shrimp products by conducting handling and processing the shrimp in accordance with the HACCP concept.
\end{abstract}

\section{KEY WORDS}

Frozen tiger shrimp, quality, food safety, HACCP, Central Java, Indonesia..

Shrimp is one of Indonesia's fishery commodities which remains excellent and able to contribute significantly and quickly to Indonesia. This is due to the demand of shrimp. Both the domestic market and the international markets tend to have increasing demand from time to time. The value of shrimp exports takes the first rank for fishery products besides tuna. According to the data that has been released by the Central Bureau of Statistics (BPS), Indonesia's shrimp exports reached 136.3 thousand tons with a value of US\$ 1.13 billion during January to August 2016. The shrimp export volume rose $6.84 \%$, while the value of shrimp exports rose $3.75 \%$. Currently, Indonesia's shrimp production has taken the second position after India in the United States shrimp market. Every year, Indonesian shrimp entering the United States keeps increasing. In 2013, the number of shrimp exports to the United States booked the figure of $64,520.6$ tons. That number increased in 2014, which reached 85,838 tons, or it rose about $33 \%$, but in 2015 shrimp exports to America decreased with the export volume of 82,263.8 tons (Central Statistic Bureau, 2016). In the region of Central Java alone, the shrimp export value increased significantly. In 2014, the export value of Central Java shrimp reached 1,495,879 tons, reaching another 1,495,850 tons in 2015 and again reaching another increase of 2,992,633 tons in 2016 (BKIPM, 2017).

Shrimp that is going to be exported must be kept away from any harmful ingredients to maintain its quality. A food product including shrimp that is proven to contain harmful substances in both biological, chemical and physical materials will not be able to penetrate the export market, because the quality requirements to enter the export destination countries are very strict. Examination and control of chloramphenicol levels on frozen shrimp that is going to be exported are essential to ensure the food quality and safety. Chloramphenicol is one of nine types of food additives that is prohibited in Indonesia ( Ministry of health Republic Of Indonesia, 1999 ). Even the WHO (World of Health Organization) applies zero tolerance rules to the content of chloramphenicol in shrimp (Islamulhayati, 2005). Some time ago, the issue of chloramphenicol residue was spreading widely after the release of the European Union Decision on 27 September 2001 which stated that chloramphenicol contamination of $0.075 \mathrm{ppb}$ in Indonesian export shrimp products entering EU countries Setyaningsih (2004); WHO (2007) had been detected. Similarly, shrimp exports to China and Japan in 2006 and 
2007 were rejected due to the suspicion of that the shrimp contained chloramphenicol residues (Putro, 2008). The worst situation happened in 2011 as there were massive rejections from the European Union on Indonesian shrimp export products due to the chloramphenicol content.

Perishable shrimp warranty becomes the main reason to strive for better handling. The most commonly exported shrimp is the shrimp that has been frozen or processed (frozen shrimp). The shrimp freezing is one of the process of fishery products with the purpose of preserving the food. The freezing process is expected to inhibit the growth of microorganisms, enzyme activity and to retain chemical reactions that occur in shrimp (Sunarya, 2014). Shrimp processing should be done in accordance with the standards to obtain products with guaranteed quality. Raw materials and auxiliary materials should be recognized in order to receive proper process. Currently, frozen shrimp processing companies in Indonesia with the purpose of exporting the products have applied HACCP. Nevertheless, in order to avoid economical loss in exporting the frozen shrimp and to increase competition of shrimp export in anticipating the ASEAN Economic Communities, a good quality control system which is in accordance with the standards that are specified by the importing countries such as the United States, Japan and EU countries needs to be established. The purpose of this research is to identify the quality and safety of frozen tiger shrimp products that is produced by the Fish Processing Unit in Central Java in accordance with the HACCP concept including GMP and SSOP. The quality analysis result is then used to formulate strategies which are going to be used to make corrections should there be any, in order to maintain and to control the quality of frozen shrimp products by companies and to reduce product defects.

\section{MATERIAL AND METHODS OF RESEARCH}

The research was conducted in February until September 2017 with the objects of research emphasized on 3 Fish Processing Units (FPU) that process frozen shrimp in Central Java, Indonesia. The subjects of this research were frozen shrimp processing in the Fish Processing Units. The research object was Frozen Tiger Shrimp, frozen shrimp sampling was done 3 (three) times periodically. Further steps include organoleptic, microbiology and chloramphenicol test to the sample of raw materials and end products of frozen shrimp. The laboratory tests were conducted at Laboratorium Pembinaan dan Pengujian Mutu Hasil Perikanan Propinsi Jawa Tengah (the Laboratory of Fishery Product Quality Assurance Testing of Central Java Province).

The parameters observed in this study include the prevention efforts on received products in the fish processing unit of both caught and cultivated shrimp. The analysis was done qualitatively and quantitatively in the form of processing data test of organoleptic, microbiology and chemistry.

The scope of activities in the processing unit includes:

1. Sanitation Standard Operating Procedures (SSOP).

2. Good Manufacturing Practices (GMP).

3. Hazard Analysis Critical Control Point (HACCP).

4. Quality of products / raw materials that are received in the processing unit and the ones after the production process, to determine the effectiveness of quality assurance and food safety in handling frozen shrimp products. The observations was done by having the organoleptic and microbiology test on the shrimp samples before and after processing and also the chloramphenicol content test on the raw material samples of tiger shrimp. The microbiological tests include TPC test (SNI 01-2332.3-2006), Escherichia coli test (SNI 01-2332.1-2006), and Salmonella test (SNI 01-2332.22006).

Data used in this research are primary and secondary data. The primary data was obtained by having observation and interview. Observations were conducted by observing the activities of the frozen shrimp processing and handling directly in the three units of frozen shrimp processing. On the other hand, the interview was conducted on the employees who 
carry out the handling of frozen shrimp by giving a questionnaire about quality assurance in regards to the handling of frozen shrimp in their work place.

The data analysis was done quantitatively. The quantitative analysis in the form of data processing of quality test result (Organoleptic, microbiology / TPC / TPC and chloramphenicol test), done by using different test (t test). The quantitative analysis was done by applying T-test to compare the mean value of quality test (organoleptic, microbiology and chloramphenicol) between raw material and final product. If the result of the T-test calculation is bigger than the table in the real determined stages $(5 \%)$, it means that the handling and processing of the frozen tiger shrimp causes a significant change to the quality of shrimp, so the supervision and control should be done more intensively.

$$
\mathrm{t}=\frac{\overline{\mathrm{X}}_{1}-\overline{\mathrm{X}}_{2}}{\mathrm{~S} \sqrt{\frac{1}{\mathrm{n}_{1}}+\frac{1}{\mathrm{n}_{2}}}}
$$

With:

$$
\mathrm{s}=\sqrt{\frac{\left(\mathrm{n}_{1}-1\right) \mathrm{S}_{1}^{2}+\left(\mathrm{n}_{2}-1\right) \mathrm{S}_{2}^{2}}{\mathrm{n}_{1}+\mathrm{n}_{2}-2}}
$$

Notes:

$\mathrm{t}$ : difference value between the mean of quality test value before and after the stage that is considered as critical point;

$\mathrm{n}_{1}$ : number of samples in quality test before observed stages;

$\mathrm{n}_{2}$ : number of samples in the quality test after the observed stages;

$\mathrm{S}_{1}^{2}$ : sample variance of quality test result before observed stages;

$\mathrm{S}_{2}{ }^{2}$ : sample variance of quality test results after observed stages;

$\mathrm{X}_{1}$ : mean test value before observed stages;

$\mathrm{X}_{2}$ : mean test value of the quality test after observed stages.

\section{RESULTS AND DISCUSSION}

Organoleptic Observation. The result of organoleptic analysis shows the processing and handling of frozen shrimp at Fish Processing Unit (FPU) 1, FPU 2 and FPU 3 are able to maintain the organoleptic value of shrimp with the value of $7-8$.

Table 1 - Organoleptic Test Results

\begin{tabular}{ccccccc}
\hline & \multicolumn{5}{c}{ Organoleptic Test Results (scale: 1-9) } \\
\cline { 2 - 7 } Sample & \multicolumn{2}{c}{ FPU 1 } & \multicolumn{2}{c}{ FPU 2 } & \multicolumn{2}{c}{ FPU 3 } \\
\cline { 2 - 7 } & Raw Material & End Product & Raw Material & End Product & Raw Material & End Product \\
\hline 1 & 7 & 8 & 7 & 8 & 7 & 7 \\
2 & 8 & 8 & 8 & 8 & 7 & 7 \\
3 & 7 & 7 & 8 & 7 & 7 & 8 \\
\hline Mean & $7,33 \pm 0,577$ & $7,67 \pm 0,577$ & $7,67 \pm 0,577$ & $7,67 \pm 0,577$ & $7,00 \pm 0$ & $7,33 \pm 0,577$ \\
\hline
\end{tabular}

The data analysis using T-test difference with probability value of 0,05 got the result that t-value at FPU 1 is 0,423 , at FPU 2 is 1.0 and at FPU 3 is 0,423 . This indicates that the frozen shrimp handling and processing performed by FPU 1, FPU 2 and FPU 3 showed no significant difference between organoleptic value of shrimp raw material and frozen shrimp final product.

The activity of handling and processing of frozen tiger shrimp conducted by the Fish Processing Units by applying cold chain is able to maintain the organoleptic value of shrimp. The fishery products handling by means of temperature thorough monitoring through cold chain management is proven to be able to maintain the quality of the product (Tsironi et al., 
2015). The freezing process that is carried out on shrimp products can inhibit the growth of microorganisms, enzyme activity and obstruct chemical reactions that occurs in shrimp (Sunarya, 2014). The quality decrease of frozen foods, meats and fishery products due to chemical reactions such as loss of nutritional value and other chemical reactions (color change and rancidity in foods) happened because of uncontrolled temperature changes of the food products (Giannakourou \& Taoukis, 2015; Giannoglou et al., 2014).

TPC Test of Content. Food materials damage can occur due to the ongoing process either quickly or slowly depending on the type of food and its environmental conditions in which the food is placed (Wijayanti, 2011). In order to know the extent of the food damage, whether it is safe or not to be consumed, a microbiology test should be conducted. The microbiology observation is commonly used to determine the freshness of the fishery products by calculating the bacterial population based on the Total Plate Count (TPC) method.

Table 2 - Test Result of TPC Shrimp Content

\begin{tabular}{ccccccc}
\hline \multirow{2}{*}{ Sam } & \multicolumn{5}{c}{ Test Result of TPC (col/ml) } \\
\cline { 2 - 6 } ple & \multicolumn{2}{c}{ FPU 1 } & \multicolumn{2}{c}{ FPU 2 } & \multicolumn{2}{c}{ FPU 3 } \\
\cline { 2 - 7 } & Raw Material & End Product & Raw Material & End Product & Raw Material & End Product \\
\hline 1 & $1,0.10^{3}$ & $1,64.10^{3}$ & $0,65.10^{3}$ & $1,45.10^{3}$ & $3,4.10^{3}$ & $2,95.10^{3}$ \\
2 & $2,9.10^{3}$ & $1,0.10^{3}$ & $20,0.10^{3}$ & $1,45.10^{3}$ & $2,36.10^{3}$ & $2,7.10^{3}$ \\
3 & $2,3.10^{3}$ & $2,3.10^{3}$ & $1,0.10^{3}$ & $0,77.10^{3}$ & $4,15.10^{3}$ & $0,65.10^{3}$ \\
\hline \multirow{2}{*}{ Mean } & $2,67.10^{3} \pm$ & $1,65.10^{3} \pm$ & $7,22.10^{3} \pm$ & $1,22.10^{3} \pm$ & $3,30.10^{3} \pm$ & $2,10.10^{3} \pm \pm$ \\
& $0,97.10^{3}$ & $0,65.10^{3}$ & $11,07.10^{3}$ & $0,39.10^{3}$ & $0,89.10^{3}$ & $1,26.10^{3}$ \\
\hline
\end{tabular}

The results of laboratory tests on TPC content showed that the processing and handling of frozen shrimp on FPU 1, FPU 2 and FPU 3 has been able to maintain the amount of TPC content in shrimp products according to SNI standard.

The T-test result on TPC content of shrimp samples at FPU 1 is 0806 , at FPU 2 is 0.441 and FPU3 is 0.412 . The result of the T-test with probability value of 0,05 shows that there is no significant difference of the TPC value between raw material and frozen shrimp final product. However, the overall laboratory analysis showed that there was a decrease in TPC content in shrimp final products although not significantly significant. The TPC content of frozen shrimp at FPU 1, FPU 2 and FPU 3 still meets the SNI standard of frozen shrimp that is $<5,0 \times 10^{5} \mathrm{col} / \mathrm{ml}$. The activity of handling and processing of frozen shrimp conducted by the FPUs by keeping cold chain of product is able to prevent the increase of bacterial population during the production process so that the shrimp freshness can be maintained. The increasing of bacterial population in foodstuff during storage shows the decrease of freshness level of fish (Liviawaty and Eddy, 2010). Husni et al. (2015) states that the increase and decrease of TPC can occur because fish meat is a suitable medium for bacterial growth. The shrimp processing by means of freezing is able to maintain the quality of shrimp. The use of low temperature of $0^{\circ} \mathrm{C}$ after mortality time of the fish can extend the life of rigor mortis, decrease enzymatic, bacterial, chemical and physical change process of the fish (Wibowo et al., 2014)

Eschericia coli Content Test. The results of E coli test showed that the whole process of frozen shrimp production at FPU 1, FPU 2 and FPU 3 is able to maintain the amount of Escherichia coli content from shrimp product. In shrimp raw material, it can be seen that the average of Eschericia coli content of raw shrimp protein is <2 per $25 \mathrm{gr}$. sample, after processing and handling the Eschericia coli content on shrimp product, it shows that it is still below the threshold figure that is $<2$ per $25 \mathrm{gr}$. sample.

The processing and handling of shrimp conducted by the three fish processing units are able to minimize the content of $E$ coli shrimp products, so it is safe to be consumed. One of the processing and handling stages of shrimp to minimize the microbial content is by washing. The fish washing process can reduce the microbes at the surface up to $80-90 \%$ (Mountney and Gould, 1988). The fish washings should be performed on running water to prevent cross-contamination. Dirt and microbes will soon be washed away so it does not contaminate the fish. One way to maintain the quality of shrimp products is done by applying 
cold chain method. At low temperatures (cold and freezing), the biochemical processes in shrimp which leads to the deterioration of shrimp quality can be slowed down. The process of bacterial growth in the shrimp body can also be inhibited. Thus, the freshness of shrimp will be maintained (Junianto, 2003).

Table 3 - The Eschericia Coli Content Test Result

\begin{tabular}{ccccccc}
\hline \multirow{2}{*}{ Sample } & \multicolumn{5}{c}{ Eschericia coli Test Result (Most Probable Number or MPN/gr) } \\
\cline { 2 - 7 } & \multicolumn{3}{c}{ FPU 1 } & \multicolumn{3}{c}{ FPU 2 } \\
\cline { 2 - 7 } & Raw Material & End Product & Raw Material & End Product & Raw Material & End Product \\
\hline 1 & $<2$ & $<2$ & $<2$ & $<2$ & $<2$ & $<2$ \\
2 & $<2$ & $<2$ & $<2$ & $<2$ & $<2$ & $<2$ \\
3 & $<2$ & $<2$ & $<2$ & $<2$ & $<2$ & $<2$ \\
\hline
\end{tabular}

Unprocessed and unhandled shrimp can cause potential harm to consumers. The results of a research in the United States suggests that $60 \%$ of shrimps imported from Thailand, Vietnam, India and Indonesia are contaminated (Graham, 2015). The product test results indicate the presence of antibiotic residue and the presence of bacteria such as Salmonella, Vibrio, S. Aureus, E. Coli and Listeria.

Salmonella Content Test. Some several types of pathogenic microbes have been established as indicators in determining food safety, such as $E$ coli, Salmonella, $S$ aureus, etc. The existence of these microbes in fishery products or their processed products can be used as an indicator about food security level decrease. Salmonella sources in foodstuffs are predominantly derived from animals including fishery products. Unhygienic sanitation and imperfect processing of food materials or contamination from the environment is a contributing factor to Salmonella infection in human's body (Lynch et al., 2006; Majowicz et al., 2010).

Salmonella spp. in fishery product is caused by water conditions and cultivation system, where the accumulation of the environmental contamination causes an increase in Salmonella prevalence in fishery products (Reilly \& Twiddy, 1992; Saheki et al., 1989). The Salmonella contamination in fishery products can occur from caught or harvested fish until the time it is sold in the market. Many factors can lead to Salmonella contamination, ranging from fishing or cultivation environments, handling at post-harvest moment, during transportation, and the way of handling when the fishery products are sold in both traditional and modern markets (Bhaftopadhyay, 2000; Kamat et al., 2010). The results suggest that fishery products in its fresh form becomes the source of salmonellosis, especially in fisheries which are obtained from an environment exposed to human or animal fecal waste (Mol et al., 2010; Norhana et al., 2010).

Table 4 - Salmonella Content Test Result

\begin{tabular}{ccccccc}
\hline \multirow{2}{*}{ Sample } & \multicolumn{5}{c}{ Salmonella Test Result (per 25gr) } \\
\cline { 2 - 6 } & \multicolumn{2}{c}{ FPU 1 } & \multicolumn{2}{c}{ FPU 2 } & \multicolumn{2}{c}{ FPU 3 } \\
\cline { 2 - 6 } & Raw Material & End Product & Raw Material & End Product & Raw Material & End Product \\
\hline 1 & negative & negative & negative & negative & negative & Negative \\
2 & negative & negative & negative & negative & negative & Negative \\
3 & negative & negative & negative & negative & negative & Negative \\
\hline
\end{tabular}

From the table above, it can be seen that the results of the laboratory analysis of Salmonella content in shrimp raw materials used in the production process at FPU 1 , FPU 2 and FPU 3 in Central Java showed negative results per $25 \mathrm{gr}$ samples. While on frozen shrimp products which have been handled and processed showed negative result per $25 \mathrm{gr}$ sample. Overall the production process of frozen shrimp at FPU 1, FPU 2 and FPU 3 is able to maintain the amount of salmonella content from shrimp product, that is also negative per 25 gr. sample.

Based on the results of observations during the sample taking both at FPU 1, FPU 2 and FPU 3 indicate that the FPUs in Central Java have been able to perform the process of production and to handle the shrimp well. The FPUs have been able to apply sanitation and 
hygiene procedures in accordance with the HACCP concept. In addition, the FPUs in Central Java are also able to prevent any contamination from the environment, equipment, and also any contamination that may arise during the distribution and transportation process. Salmonella distribution in fishery products is still often found, possibly due to contamination that is derived from workers who handle the product. The results of the previous research indicate that Salmonella bacteria are still found in fishery products for export markets resulting the rejection of export of the fishery products from Indonesia (Yennie et al., 2015). Meanwhile, the prevalence of Salmonella spp. is also found in tuna loin along with the frozen tuna supply chain for export market which is collected at raw materials reception and processing process at fish processing unit (Yennie et al., 2016).

For developing countries, the incidence of salmonellosis and salmonella prevalence in the food production increases significantly (Saha et al., 2001 \& Byrd et al., 2002), transportation chain and the food processing may be the main contributing factor to cross contamination at that stage. In addition to that, contamination due to improper handling practices of transportation of food products and the use of ice and water which do not meet the requirements and also cross-contamination between foodstuffs are also becoming the major factors in the high number of Salmonella spp prevalence. (Badonia, et al., 1988; Hatha \& Lakshmanaperumalsamy, 1997; Indrajith et al., 2015).

Chloramphenicol Content Test. The cultivation of tiger shrimp is not easy to do because there are many obstacles faced by shrimp farmers, such as disease attacks caused by bacteria, viruses or fungi that causes mortality to the shrimp and shrimp larvae, so that the production levels can decrease (Nugraheny, 2001). The control of shrimp disease caused by bacteria is done by farmers by using antibiotics such as tetracycline, oxytetracycline, nitrofuran, sulphonamide and chloramphenicol groups (Nisha, 2008; WHO, 2007).

The following is a table of chloramphenicol content test results on shrimp samples of 3 FPUs production in Central Java.

Table 5 - The Content Test Result of Shrimp Chloramphenicol

\begin{tabular}{|c|c|c|c|c|c|c|}
\hline \multirow{3}{*}{ Sample } & \multicolumn{6}{|c|}{ Chloramphenicol Test Result $(\mu / \mathrm{kg})$} \\
\hline & \multicolumn{2}{|c|}{ FPU 1} & \multicolumn{2}{|c|}{ FPU 2} & \multicolumn{2}{|c|}{ FPU 3} \\
\hline & Raw Material & End Product & Raw Material & End Product & Raw Material & End Product \\
\hline 1 & 0,121 & 0,108 & 0,138 & 0,083 & 0,092 & 0,12 \\
\hline 2 & 0,096 & 0,083 & 0,128 & 0,088 & 0,093 & 0,075 \\
\hline 3 & 0,064 & 0,074 & 0,091 & 0,12 & 0,072 & 0,103 \\
\hline Mean & $0,094 \pm 0,029$ & $0,088 \pm 0,018$ & $0,119 \pm 0,025$ & $0,097 \pm 0,020$ & $0,086 \pm 0,012$ & $0,099 \pm 0,023$ \\
\hline
\end{tabular}

The result of the laboratory test shows that the handling and the processing of frozen shrimp at the FPU 2 is able to decrease the amount of chloramphenicol content in frozen shrimp with the percentage of $18,48 \%$, whereas the handling and processing activities of the frozen shrimp at FPU 1 can decrease the chloramphenicol content in frozen shrimp with the percentage of $6,38 \%$. The selection of raw materials quality with low initial chloramphenicol content causes the content of it in frozen shrimp end products at FPU 1 to be lower in comparison to the FPU 1 frozen shrimp products, while at the FPU 3, the chloramphenicol content increases.

Different T-test result in chloramphenicol content on shrimp with probability value of 0,05 at FPU 1 is 0,559 , at FPU 2 is 0,485 and at FPU 3 is 0,480 which indicate that there is no significant difference of chloramphenicol content between raw material and end product of frozen shrimp. However, the overall results of the laboratory analysis showed that there was a decrease in TPC and chloramphenicol contents in shrimp final products although the value is not so significant.

The examination and control of chloramphenicol levels in frozen shrimp which is prepared to be exported are essential to ensure the food quality and safety. Chloramphenicol is one of the nine types of food additives which are prohibited in Indonesia ( Ministry Of Health Republic Indonesia, 1999). Even the WHO (World Health Organization) applies zero tolerance rules to the content of chloramphenicold in shrimp (Islamulhayati, 2005). Some time ago the issue of chloramphenicol residue was spreading so widely after the release of 
the European Union Decision of 27 September 2001 which stated that they had detected chloramphenicol contamination of $0.075 \mathrm{ppb}$ in Indonesian export shrimp products which entered the EU countries (Setyaningsih, 2004; WHO, 2007). Similarly, the shrimp exports to China and Japan in 2006 and 2007 were rejected on the suspicion of containing chloramphenicol residues (Putro, 2008).

The unawareness of the farmers in regards to the use of antibiotics, especially chloramphenicol is very dangerous. The abuse of the antibiotics resulted in the lagging of chemicals as a residue in shrimp meat that in a certain amount and in a long period of time will cause health problems that are the occurrence of aplastic anemia in the consumer, the cause of gray syndrome in infants and the resistance to the antibiotic (Nisha, 2008; Garrod, 1971). The consumption of food containing chloramphenicol residues bit by bit can make the disease bacteria become more resistant to chloramphenicol and the disease can no longer be treated with chloramphenicol. Consumption of tiger shrimp containing chloramphenicol residue in large quantities and in a long period of time will bring the impact of aplastic anemia illustration (Ismulhayati et al., 2005). Chloramphenicol which broad spectrum in small amounts can also lead to the resistance of previously sensitive bacteria (Setiabudi \& Kunardi., 1995 ).

\section{CONCLUSION}

Based on the results of research regarding quality analysis and food safety on the handling and processing of frozen tiger shrimp in Central Java showed that fish processing unit in Central Java has been able to apply the principles of HACCP in the handling and processing process of the frozen shrimps. The results of the laboratory analysis towards the shrimp raw material samples and frozen shrimp final product showed that fish processing units in Central Java are able to maintain organoleptic value of frozen shrimp and decrease the content of TPC, E coli, Salmonella and chloramphenicol frozen shrimp.

\section{REFERENCES}

1. Badonia, B., Ramachandran, A., \& Sankar, T. (1988). Quality problems in fish Processing. Indian Fish. Assoc, 18, 283-287.

2. Byrd, J., Hargis, B., Corrier, D., Brewer, R., Caldwell, D., Bailey, R., Stanker, L. (2002). Fluorescent Marker for The Detection of Crop and Upper Gastrointestinal Leakage in Poultry Processing Plants. Poult. Sci, 81, 70-74.

3. Firlieyanti, A. (2005). Evaluasi Bakteri Indikator Sanitasi di Sepanjang Rantai Distribusi Es Batu di Bogor. Bogor: Departemen Ilmu Teknologi Pangan, Fakultas Teknologi Pertanian. IPB.

4. Fish Quarantine and Inspection Agency. (2017). BKIPM Inside Statistic. Semarang, Indonesia: Fish Quarantine and Inspection Agency.

5. Garrod, L., \& O'Grady, F. (1971). Antibiotic and Chemotherapy (Vol. 3rd Edition). Edinburgh: E. \& S. Livingstone.

6. Giannakourou, M. C., \& Taoukis, P. S. (2003). Application of a TTI-Based Distribution Management System For Quality Optimization Of Frozen Vegetables At The ConsumerEnd. Journal of Food Science, 68(1), 201-209.

7. Giannoglou, M., Touli, A., Platakou, E., Tsironi, T., \& Taoukis, P. (2014). Predictive modeling and selection of tti smart labelsfor monitoring the quality and shelflifeof frozen seafood. Innovative Food Science\& Emerging Technologies, 26, 294-301.

8. Graham, K. (2015). Over Half Of U.S. Frozen Shrimp Contaminated With Bacteria.

9. Hatha, M., \& Lakshmanaperumalsamy, P. (1997). Prevalence of Salmonella in Shellfish and Crustaceans from Markets in Coimbatore, South India. J. Food Microbiol., 14, 111116.

10. Husni, A., AK, B., \& SA, B. (2015). Peningkatan Daya Simpan Ikan Kembung dengan Ekstrak Etanolik Padina sp. Selama Penyimpanan Suhu Kamar. Jurnal Pengolahan Hasil Perikanan Indonesia, 18(1), 1-10. 
11. Indrajith, S., Athmanathan, B., Subbaraj, D., Meganathan, V., Arockiaraj, J., Woodrowwilson, J., \& Karuppannan, S. (2015). Incidence and antibiotic resistant profiles of pathogenic Salmonellaspp. from different environmental and food samples...Int. J. Microbiol. Immunol, 76-83.

12. Islamuhayati, Soedjajadi , \& Ririh. (2005). ). Pengaruh Residu Khloramfenikol Dalam Udang Windu Terhadap Kejadian Anemia Aplastik Pada Mencit. J. Kesehatan Lingkungan, 1(2), 99-102.

13. Josephine, A., Morello Paul , A., \& Eckel Mizer , G. (2003). Laboratory manual and Workbook in Microbiology Applications to Patient Care. The McGraww-Hill Companies.

14. Kamat, A., Bandekar, J., Karani, S., Jadhav, R., Shashidhar, A., Kakatkar, S., Bhat, A. (2005). Microbiological Quality of Some Major Fishery Products Exported From India. In: International Atomic Energy Agency document. Proceedings of a Final Research Coordination Meeting on Determination of Human Pathogen Profiles in Food by Quality., (pp. 51-61). Mexico City.

15. Li, Y., \& M. K. (2011). Water Quality Concepts, Sampling, and Analyses. LLC, USA: Taylor and Francis Group.

16. Liviawaty, E., \& Eddy, A. (2010). Proses Penurunan dan Cara Mempertahankan Kesegaran Ikan, Penanganan Ikan Segar. Bandung: Widya Padjajaran.

17. Lynch, M., Painter, J., Woodruff, R., \& Braden, C. (2006). Surveillance For FoodborneDisease Outbreaks-United States, 1998-2002. MMWR Surveill Summ, 55, 1-42.

18. Majowicz, S., Musto, J., Scallan, E., Angulo, F., Kirk, M., O’Brien, S., Hoekstra, R. (2010). The Global Burden Of Nontyphoidal Salmonella Gastroenteritis. Clin. Infect. Dis, 50(6), 882-889.

19. Ministry of health Republic Of Indonesia. (2017, 08 01). Food Additional Materials No.1168 / Menkes / PER / X/1999. Jakarta, Indonesia.

20. Nasional Standart Indonesia;. (2014). Nasional Standart Indonesia 01-4852-1998 Sistem Analisa Bahaya dan Pengendalian Titik Kritis (HACCP) serta Pedoman Penerapannya. Jakarta: Nasional Standart Indonesia.

21. National Standart Indonesia;. (2014). National Standart Indonesia Number 2705: 2014. Jakarta: National Standart Indonesia;.

22. National Statistic Agency. (2016). Frozen Shrimp Export By Country 2005-2015. Jakarta: National Statistic Agency.

23. Norhana, M., Poolec, S., Deethah, C., \& Dykesd, G. (2010). Prevalence, persistence and control of Salmonella and Listeria in shrimp and shrimp products. J. Food Control, 21(4), 343-361.

24. Nugraheny, N. (2001). Ekstraksi Bahan Antibakteri Diatom Laut Skeletonema costatumdan Potensi Daya Hambatnya Terhadap Vibrio sp. Journal Kelautan IPB, 12.

25. Robinson, R. (2005). Fish-Catching And Handling In: Encycl. Food Microbiol. London: Academic Press.

26. Saheki, K., Kobayashi, S., \& Kawanishi, T. (1989). Salmonella Contamination Of Eel Culture Ponds. Nippon Suisan Gakkashi, 55, 675-679.

27. Santoso, S. (2004). Statistik Non Parametrik. Jakarta: PT. Elex Media Komputindo.

28. Setiabudi, R., \& Kunardi, L. (1995). Golongan Tetrasiklin dan Khloramfenikol, Farmakologi dan terapi (Vol. 4). Jakarta: Fakultas kedokteran Universitas Indonesia.

29. Setyaningsih, I. (2004). Resistensi Bakteri dan Antibiotik Alami d ari Laut. Falsafah Sains (PPS 702). Bogor: Institut Pertanian Bogor.

30. Sunarya. (2014). Mutu dan Keamanan Pangan Hasil Perikanan. Konsep dan Aplikasi Seafood Safety. Bogor: CV. The Spring.

31. Suriawira, U. (2008). Mikrobiologi Air dan Dasar-dasar Pengolahan Buangan Secara Biologis. Bandung.

32. Tookwinas, S., and Suwimon, K. 2004. HACCP in Shrimp Farming. Department of Fisheries, Thailand. J Aquaculture Asia., 9(2): 29-48.

33. Tsironi, T., Giannoglou, M., Platakou, E., \& Petros, T. (2015). Training of SMEs for Frozen Food Shelf Life Testing and Novel Smart Packaging Application for Cold Chain Monitoring. International Journal of Food Studies, 4, 148-162. 
34. Upadhyay, B., Utrarachkij, F., Thongshoob, J., Mahakunkijcharoen, J., Wongchinda, N., Suthienkul, O., \& Khusmith, S. (2010). Detection of Salmonella in Shrimp Enrichment Culture by Polymerase Chain Reaction. Southeast Asian. J. Trop Med Public Health, 41(2), 426-435.

35. Wibowo, I., Darmanto, Y., \& Angga, A. (2014). Pengaruh Cara Kematian dan Tahapan Penurunan Kesegaran Ikan Terhadap Kualitas Pasta Ikan Nila (Oreochromis niloticus). Jurnal Pengolahan dan Bioteknologi Hasil Perikanan, 3(3), 95-103.

36. Wijayanti, R. (2017, 9 12). Kerusakan Bahan Pangan. Retrieved from Food Scientech: http://foodscientech46.wordpress/2011/

37. Yennie, Y., Gunawan, Kusmarwati, A., Indriati, N., Wibowo, S., \& Kusumaningrum, H. (2016). Kajian Risiko Salmonella Pada Tuna Tangkapan Nelayan Kecil Ambon. Laporan Teknis Peneltian dan Pengembangan TA.2016. Jakarta: Pusat Penelitian dan Pengembangan Daya Saing Produk dan Bioteknologi Kelautan dan Perikanan, KKP.

38. Yennie, Y., Kusmarwati, A., Hermana, I., Ariyani, F., Wibowo, S., \& Kusumaningrum, H. (2015). Kajian Risiko Mikrobiologi Salmonella pada Produk Udang Beku. Laporan Teknis Penelitian dan Pengembangan. Jakarta: Balai Besar Penelitian dan Pengembangan Pengolahan Produk dan Bioteknologi Kelautan dan Perikanan-KKP. 